DOI:10.1515/hssr -2017-0001

\title{
A Critical Threshold
}

Simona Modreanu*

"Alexandru Ioan Cuza" University of Iasi, Romania

Only ignorance produces disorder, disharmony. So first we must overcome ignorance through intimate knowledge from within. This is a great virtue, which purifies the soul, if necessary. Its origin is the plan of the supersensible, the spiritual essences, where one can enjoy the contemplation of ideas. But for this we need, as Plotinus said, "another view", in fact an entire change of the self, produced by removing the slavery of the senses and awaiting in silence the arising of the One in us. Only then can we contemplate what is eternal. To contemplate (theoria) is also a way of knowing, ecstatic, in the undying light of supreme virtue.

We tend towards a higher knowledge, that goes beyond the world of "phenomenal" and the modern era, trying to reunite with existence, and eliminating contrasts between subject and object, between I and non-I, re-identifications that need to be experienced at all levels of consciousness, from pure thought to the obtuse earthly limit, which the Vedic sages called bhuta, our ideal is being not one's full belly, but service to the virtues suggested by divine attributes: good, truth, beauty, justice, etc.

Mental mechanisms that reigned in past centuries are about to be extinguished, and our society has reached a critical threshold of representation. We live a metamorphosis, a change to a new Weltanschauung, towards a new kind of civilization, which involves the regeneration of the Spirit, including the human spirit.

\footnotetext{
Faculty of Letters, "Alexandru Ioan Cuza" University of Iasi, 11, Carol I Bvd., 700506, Iasi, Romania; simona.modreanu@gmail.com
} 
In Gorgias, Socrates talks about a plan of moral reality, detached from the material world where the tyrants and torturers always win, and the righteous remain with their tears. But Socrates reveals the existence of another level of reality, justice and moral order, in which glory takes the part of the former innocent victims and where perpetrators are punished. The world contains such an underlying order, that can barely be seen, one of true values, of the right, which ultimately commands, because it is governed by truth and has force, as I have previously mentioned.

Thus politics can be moral in spite of what we have been taught to believe in the modern era, the truth and good feelings occur in politics, and can even make it better, because ultimately results matter. Nothing can withstand the power of truth, even if sometimes the road is long and requires caution. In general, for us, men, the road to wisdom is tortuous, such as the one from all initiatic routes. But by bestowing with wisdom, one becomes worthy of the living knowledge of the truth.

Thus, the world can change not only through violence - and we see it everywhere around, at all levels -, but also by making an appeal to the moral power in us and addressing our conscience and humanity opponents, directly or indirectly. "When I am weak, then I am strong", says St. Apostle Paul. And the oppressor will find an equal enemy and will quickly dissipate his so-called forces. There is a responsibility for everything we do and everything is paid. The opponent must be caught in the trap of their own moral. There are some immutable laws supporting the universe with justice. No one fools anyone, and the rebound effect determines our getting what we give, in a moral order, where forms and time may vary.

Moral order does not admit violence. We answer hatred with love, and to love we answer with humbleness. We rather help the violent one, patiently persuading him that his error may harm everyone. It's very hard to turn the other cheek, but there is no other viable way. It's very hard to forgive, but he who does it is strong. It is very difficult to love your enemy, but only that is true love, that is almost frightening. Gandhi strove systematically to believe that the errors of others were his own, which we might call a totalitarianism of purity, excluding sex, flesh, clothes made by others, etc. "The spirit without flesh is perfect and is everything we need," he said, sublime and admirable, even ideal. 
Therefore, the road of emancipation is spiritual and moral, and life must be passed through the filter of values. Thus the individual has something to gain together with society, and economy, all being arranged on the path. Gandhi was a simple man who knew Christianity through the works of Tolstoy, but the intransigence of its principles freed a great civilization and defeated a great empire. Such individuals are providential, or the people really have the leader that they deserve. However, the role of the educated and spiritualized elite is huge, together with that of moral values. Socrates, just like Gandhi, was killed for them. We had a Havel, we had a Mandela, we had Saint John Paul II, maybe there are others, but too little to change the world and maintain it that way.

Unless we recall that there are universal human values, there is a unity at its base and we still have, as humans, more things that bring us closer than things that separate us. Selfishness and individualism complicate things, mixing evaluation criteria or, worse, perverting them. You can not impose a way of life, such as the Western, to the whole world. Rules of behavior and of evaluation are different, so we divide the world into blocks, with the risk of a new major conflict.

The world, however, will remain plural; there is not a single truth about human beings, so there cannot be a dominator project. But there are common traits that can become linking elements, through change, with fewer geographic and knowledge limitations. The force lies within the ethics and the truth. With this understanding each one of us should begin to shine within, to do a clean up inside and then see that we can find friendlier terms to enter into relationship with each other. For problems do not come from the other, but from ourselves, and they would not exist if they had not found similarities in us. 


\section{Biographical note}

Simona Modreanu is a $\mathrm{PhD}$ professor of French and Francophone literature at the Faculty of Letters of the "Alexandru Ioan Cuza" University of Iasi. She is also an essayist and a translator, an active member of the CIRET (Centre International de Recherches et Etudes Transdisciplinaire), Paris and co-director of the Transdisciplinary Studies Center of the University of Iasi. She directed the Romanian Cultural Center in Paris (1991-2001) and the Junimea Publishing House in Iasi (2008-2014). Main publications: Eugène Ionesco on l'agonie de la signifiance (ed. Axis, Iasi, Roumanie, 2002), Le Dieu paradoxal de Cioran (Paris, Ed. du Rocher, 2003), Cioran (Paris, Oxus, 2004), Lecturi nomade (Iasi, Junimea, 2006), Lecturi sedentare (Iasi, Junimea, 2010), Lecturi infidele (Iasi, Junimea, 2014), L'Espace identitaire dans la littérature francophone contemporaine (Iasi, Ed. Univ. Al.I.Cuza, 2016). 